\title{
Farm Size and Land Productivity Relationships in Pakistan
}

\author{
MAHMOOD HaSAN KHAN*
}

\begin{abstract}
The study focuses on productivity differences due to farm size. Using farm size data, it suggests that in Pakistan large farms are relatively more productive because of their greater use of "non-traditional" inputs. The input intensity of large farms derives from market distortion induced by public policy. Agricultural policy should therefore concentrate on eliminating market distortions, by measures like ceiling on land holdings and a wider diffusion of farm extension services and credit.
\end{abstract}

Productivity differences by farm size have been observed in many underdeveloped countries. The most commonly stated proposition is that there is an inverse relationship between output per acre and farm size. Attempts have been made to explain the apparently higher land productivity on small farms by positing the hypothesis that these farms make greater use of the variable inputs per acre $[1,2]$. Often it has been observed that small farms consume greater amounts of "traditional" inputs, particularly of human and animal labour. It is to the relative intensity of the use of these inputs on small farms that their higher land productivity is attributed. Whether small farms are more productive than large farms is a question of central interest to policy makers because on an adequate answer to this question depends the quality of decisions about land reform.

In Pakistan, following the relatively rapid adoption of new technology associated with the "Green Revolution" in the Sixties, questions have been raised about the apparent differences in productivity levels and in access to income-earning opportunities between large and small farms. This study analyses the issue of land productivity and farm size and relates it to the use of inputs and their availability in Pakistan.

\section{HYPOTHESES}

In order to analyse the relationship of land productivity and farm inputs by farm size, the following hypotheses have been formulated:

*The author is a Professor of Economics at the Simon Fraser University, Burnaby, B.C. Canada. He thanks an anonymous referee and the Editor of The Pakistan Development Review for their comments. However, he alone is responsible for any errors or omissions in the article. 
1. "Large" farms have higher land productivity than "small" farms; or, the former arè more efficient than the latter.

2. The higher land productivity on large farms results from a greater use of "non-traditional" inputs, which are more efficient than the "traditional" inputs.

3. A more intensive use of the "non-traditional" inputs on large farm reflects the influence of non-market forces (or market imperfections), which militate against the owners of small farms.

The first two hypotheses have been tested in this paper by using a CobbDouglas production function. Homogeneity tests have been performed on inputs to differentiate them with respect to their effect on the output per acre. The last hypothesis has been tested by using data on input subsidies, wages and credit.

\section{DATA AND METHODOLOGY}

The data were collected by the author in 1974 from a randomly selected sample of 732 irrigated farms in the Indus basin [6]. The collected information related to each crop and input separately for each farm. Farms have been grouped into two sizes, namely (1) small (25.0 acres or less), and (2) large (over 25.0 acres). This classification can be justified for at least two reasons. Firstly, the average size of the sample farms (whose area ranges between 5.00 acres and 110.0 acres) is 34.0 acres. Secondly, small farms range from 4.0 acres to 24.0 acres (with 14.0 acres as the average), and large farms vary from 27.0 acres to 110.0 acres (with an average of 51.0 acres). ${ }^{1}$ It is realistic to assume that the technologies used on the farms within each of the two classes could not have been very dissimilar because the range of size is not very large in either of the groups.

A Cobb-Douglas production function is used in this paper to depict the crop production process. The (natural) $\log$ transformation of this function is estimated by the ordinary least-squares method. The estimating equation is:

$$
\ln Y=b_{0}+b_{1} \ln \left(X_{1}\right)+b_{2} \ln \left(X_{2} / X_{1}\right)+b_{3} \ln \left(X_{2} / X_{1}\right)+b_{4} \ln \left(X_{4} / X_{1}\right) \ldots(
$$

where

$\mathrm{Y}=$ value of output of all crops in rupees;

$\mathrm{X}^{1}=$ cropped area in acres;

$\mathrm{X}^{2}=$ expenditure on chemical fertilizers in rupees;

$\mathrm{X}^{\mathbf{3}}=$ family and hired labour in mandays; and

$\mathrm{X}^{\mathrm{s}}=$ expenditure on animal labour and farm machinery in rupees.

Values of the specified variables have been derived from the information given by the respondents for all crops. All inputs, except land, are expressed in per

\footnotetext{
${ }^{2}$ See Khan $[6$, p. 9].
}

acre terms, so the coefficient for land minus unity provides a test for the returns to scale [1, pp. 1375-77],

The Cobb-Douglas production function has been selected because of its computational efficiency and its consistency with the theory of production. A word is in order on the choice of the variables and their aggregation in the estimating equations. The selection of the value of the total crop production, $\mathbf{Y}$, as the dependent variable implies the assumption that crop composition across farms is identical. While this assumption does not strictly hold for sample farms, about 80 percent of the farm output is of wheat, rice, cotton and sugarcane. There is still the probability that some farms of a particular size may grow more of high-value crops, which may result in a biased estimation of the returns to scale in that it may in fact be only a crop-composition effect. This would suggest that either single crop functions should have been analysed or total production functions should have been estimated for mono-crop regions [1, pp. 1374-75]. The choice of a total crop function is justified for (a) there is no significant correlation of farm size with high-value or low-value crops, and (b) the allocation of given inputs on any single activity (crop) on a farm is not made in isolation from all other feasible or competitive activities (crops). Furthermore, this study seeks to analyse land productivity differences by farm size and not inter-crop allocative efficiency.

Among the independent variables, land, $X_{1}$, is represented by the total cropped area. A function with the net sown area (if taken alone) would have affected the returns to scale as the cropping intensity was different from one. Also, since $\mathrm{Y}$ is the value of the total farm output, $\mathrm{X}_{1}$ should be the total cropped area.

Inputs like irrigation water and farmyard manure have been excluded from the estimated equations because of the problem of multicollinearity. For instance, the correlation coefficient of water with land exceeded 0.85 . Secondly, no proper measure was available which could represent the flow of water as an input in the function. Assuming a given relation between the number of irrigations (which each farmer reported) and the volume of the irrigation water applied (which was assumed as a standard), the resulting measure (acre-inches) would obviously be a poor proxy for the water input. Finally, since all farms in the sample are irrigated, economies of scale could not be explained by the exclusion of water as a separate variable.

The fertilizer variable, $\mathrm{X}_{2}$, aggregates nitrogenous and phosphatic fertilizers, because the latter type is used in a very small quantity and performs a complementary function with the nitrogenous fertilizer.

The aggregation of hired labour with the family labour as $X_{3}$ and of farm machinery with animal labour as $\mathrm{X}_{4}$ is based on the assumption that they have a homogeneous efficiency effect on the output. However, since the test for land productivity and the returns to scale indicates that large farms differ significantly from small farms, these inputs have been disaggregated for a heterogeneity test 
in equation (2). The aggregation of animal labour with farm machinery is. achieved by adding their expenses.

\section{RESULTS AND INTERPRETATION}

The first hypothesis, viz. that large farms are more productive per acre than small farms, has been tested by estimating equation (1). In Table 1, Regressions I to IV show results for (a) all farms jointly, (b) large farms, (c) small farms, and (d) pooled data for all farms, with the dummy variable taking the value of one for large farms and of zero otherwise.

All coefficients have turned out to be highly significant, with the expected signs. A comparison of the intercept and regression coefficients on large and small farms by the covariance test on the pooled data in Regression IV has revealed that large farms have a higher intercept: the value of the dummy variable, $\mathrm{D}$, is 0.0888 , and significant at the 0.01 level. This suggests that large farms are about 9 percent more productive than small farms. Furthermore, since all factors have been defined per acre, the land coefficient $\left(b_{1}\right)$ in Regression $I$ is the sum of all the factor elasticities. Its value (1.0947) clearly indicates. increasing returns to scale. In a separate regression of the output per acre on acreage, the coefficient $(0.0331)$ is positive and significant at the 0.01 level, indicating that the output per acre increases with the farm size.

The second hypothesis, noted in the previous section, has been tested in two stages. Firstly, in Table 2, Regressions I to V have been used to test if the use of inputs per acre is related to farm size. In every case, the coefficient is significant at the 0.01 level, indicating a strong relationship. The use of fertilizer, hired human labour and expenses on farm machinery per acre (Regressions I, IV and V) increases with the farm size: large farms make greater use of these inputs. The use of all human labour (family and hired) and all farm power (animal labour and farm machinery) per acre (Regressions II and III) decreases as the farm size increases. That small farms use more human labour (i.e. family labour) and farm power (i.e. animal labour) per acre is consistent with the known facts and theory. ${ }^{2}$ Indeed, in this sample, small farms use more family labour and animal labour, and large farms use more hired labour and farm machinery per acre [6, pp. 41 and 124].

Turning to the second part of our second hypothesis, if it can be demonstrated that hired labour differs from family labour and farm machinery differs from animal labour, it would become evident that small farms do not necessarily use more labour and farm power per acre in "efficiency" units [1, pp. 1380-81]. While the heterogeneity tests could be performed separately on labour and farm power, the estimated equations will not yield unbiased values. Therefore, an alternative form of equation (1) is estimated, in which the ratio of the hired to the total human labour and the ratio of farm machinery to the

${ }^{2}$ The use of labour per acre by farm size was also estimated by an equation which included fertilizer, wage rate and acreage. The land coefficient from this equation was also negative and statistically significant at the 0.01 level.

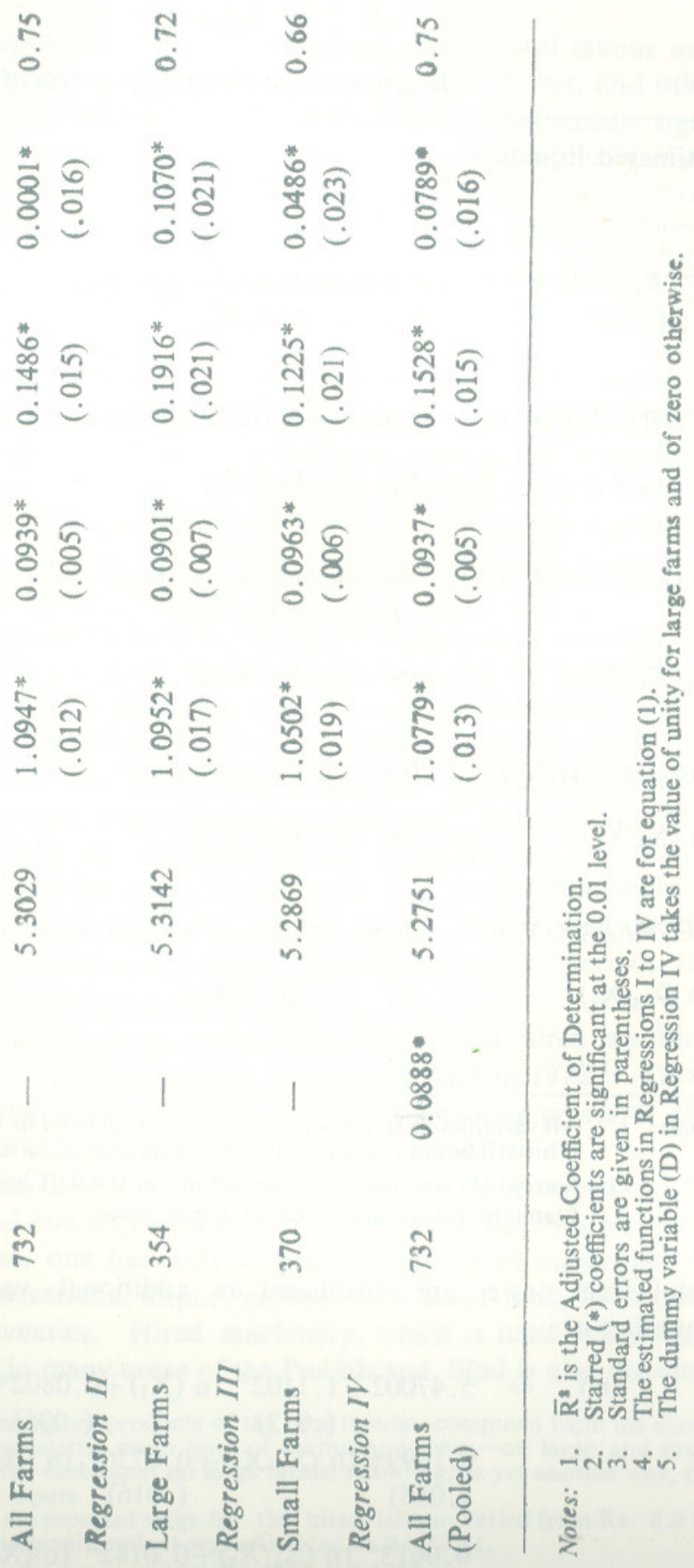


Table 2

Relationship of Farm Size to Use of Inputs

\begin{tabular}{lcc}
\hline Estimated Equation & $\begin{array}{c}\text { Constant } \\
\left(\mathrm{b}_{0}\right)\end{array}$ & $\begin{array}{c}\text { Coefficient } \\
\left(\mathrm{b}_{\mathbf{1}}\right)\end{array}$
\end{tabular}

REGRESSION I: Fertilizer Expenses Per Acre
In $\left(\mathrm{X}_{2} / \mathrm{X}_{1}\right)$
$=\mathrm{b}_{0}+\mathrm{b}_{1} \ln \mathrm{X}_{1}$
$2.3205 \quad 0.1890^{*}$

(.033)

REGRESSION II: Family and Hired Labour Per Acre
$\ln \left(X_{3} / X_{1}\right)$
$=\mathrm{b}_{0}+\mathrm{b}_{1} \ln \mathrm{X}_{1}$
$3.2071-0.4814 *$

\section{REGRESSION III: Animal Labour and Farm Machinery} Expenses Per Acre
$\ln \left(X_{4} / X_{1}\right)$
$=b_{0}+b_{1} \ln X_{1}$
$3.4980-0.0945^{*}$

REGRESSION IV: Hired Labour Per Acre

$\ln \left(\mathrm{X}_{5} / \mathrm{X}_{1}\right)$

$=b_{0}+b_{1} \ln x_{1}$

$0.4856^{\text {** }}$

\section{REGRESSION V: Farm Machinery Expenses Per Acre}
$\ln \left(\mathrm{X}_{6} / \mathrm{X}_{1}\right)$
$=b_{0}+b_{1} \ln X_{1}$
0.2342
$0.2379 *$

Notes: 1. All variables in Regressions $\mathrm{I}$ to $\mathrm{V}$ are as defined in equation (1), except $\mathrm{X}_{5}$ which is hired labour in mandays and $\mathrm{X}_{6}$ is expenses on farm machinery in rupees.

2. Starred $\left({ }^{*}\right)$ coefficients are significant at the 0.01 level.

3. Standard errors are given in parentheses.

total farm power are introduced as additional variables. The estimated equation is:

$$
\begin{aligned}
& \ln \mathrm{Y}=5.47002+1.1102 * \ln \left(\mathrm{X}_{1}\right)+0.0802 * \ln \left(\mathrm{X}_{2} / \mathrm{X}_{1}\right)+ \\
& (.012) \quad(.005) \\
& 0.1699 * \ln \left(\mathrm{X}_{3} / \mathrm{X}_{1}\right)+0.0736 * \ln \left(\mathrm{X}_{4} / \mathrm{X}_{1}\right)+ \\
& \text { (.015) (.016) } \\
& 0.0613^{*} \ln \left(\mathrm{X}_{5} / \mathrm{X}_{3}\right)+0.0182 * \ln \left(\mathrm{X}_{6} / \mathrm{X}_{4}\right) \text {, } \\
& (.007) \quad(.005)
\end{aligned}
$$

where $X_{5} / X_{3}$ is the proportion of the hired labour in the total labour and $\mathrm{X}_{6} / \mathrm{X}_{4}$ is the proportion of farm machinery in the total farm power, and other variables are defined as in equation (1). All coefficients are statistically significant at the 0.01 level. Since $b_{s}$ and $b_{6}$ are significant, the heterogeneity of the hired from family labour and of farm machinery from animal labour is clearly indicated. Fertilizer, hired labour and farm machinery are undoubtedly "nontraditional" inputs on Pakistani farms. Therefore, the higher land productivity on large farms results from the greater amounts of per acre "non-traditional" inputs used on those farms. ${ }^{3}$

The third hypothesis about the influence of the non-market forces and market imperfections on the use of inputs by farm size can be examined by analysing subsidies on inputs and wages in Pakistan. Large farms use more chemical fertilizer per acre for at least two reasons, namely, (1) large farmers' greater access to cost-free information about fertilizer use, and (2) excess demand for fertilizer at the ruling prices and the ability of the large farmers to obtain a larger proportion of the scarce facilities.

The use of hired labour on large farms can be explained, at least for this sample, by the fact that the marginal product of all labour, of the hired labour in particular, far exceeded the reported wage." This phenomenon-which incidentally counters the hypothesis of "surplus" labour-and the rapidly increasing number of workers who have fewer or no job opportunities outside agriculture would encourage a greater use of hired labour. In Pakistan, there was an impressive decline in the number of small farms during the period 1960-1972. Most striking is the case of farms under 2.50 acres: their share in the total number of farms fell from 33 percent to 14 percent and in the total farm area from 4 percent to 1 percent. During the same period, the share of large farms increased significantly $[8,9]$.

The agricultural labour force, comprising family- and hired workers, increased sharply from 7.57 million in 1961 to 11.88 million in $1972 .^{5}$ These data may provide one possible explanation of the low bargaining power of the agricultural workers and of their consequent "exploitation". 6

The use of farm machinery on large farms has been encouraged by the fact that capital in general and imported capital in particular have been greatly subsidized. For instance, one has only to look at the under-valuation of foreign exchange and concessional import policies for tractors etc., during the late Sixties and early Seventies. Hired machinery, which is itself subsidized, from government outlets in many areas of the Punjab and Sind is also directed

${ }^{3} \mathrm{~A}$ comparison of the marginal products of the used inputs-computed from the elasticities in equation (1) at the geometric mean level of output and input-on large and small farms showed a higher value for each input on large farms, reflecting, in yet another way, the

Rs, 10 For the sample farms, the reported wage for the hired labour varied from Rs.

product was estimated at Rs. 12.91 .

See, Pakistan Population Census reports for 1961 and 1972.

'Some other explanations are discussed by Bardhan [1, pp. 1382-83]. 
for use mainly on large farms. Further, the development of tubewell technology coupled with subsidized fuels, introduced a similar bias in use [10].

Finally, and perhaps most importantly, large farms in Pakistan have enjoyed more favourable, if not exclusive, access to institutional credit for capital expenditure at rates of interest which do not reflect the opportunity cost of the funds [4]. For instance, in this sample, all loans from the Agricultural Development Bank of Pakistan (ADBP) were received by farms of over 25.00 acres and the rate of interest varied from 7 percent to 8 percent per year [6, pp. 104-7]. Also, a significant proportion (35-50 percent) of the imported tractors have been financed by the ADBP [10, p. 232]. The ADBP has also been a major financing source for the installation of private tubewells in the Punjab.

\section{LIMITATIONS OF THE ANALYSIS}

The estimation results discussed in the previous section are not without limitations. For one thing, the farm-level data are cross-sectional. For another, the use of a total crop function for farms which are not from a strictly mono-crop region may have biased the returns to scale. However, as has been pointed out earlier, this should not have affected the results on land productivity. Again, the omission of "management" may have left out an explanatory variable which could account for the difference in the output per acre between farms [5, pp. 223-26]. The problem with management is that no appropriate measure can be devised for its inclusion in the given data. However, the separation of farms into two classes by size and the covariance test performed in Table 1 reflect a measure of the efficiency parameter.

\section{CONCLUSIONS AND POLICY IMPLICATIONS}

Three major conclusions emerge from the preceding analysis. Firstly, large farms are more efficient than small farms in that they have greater output per acre and there are increasing returns to scale. Secondly, the per acre use of the "non-traditional" inputs like fertilizer, hired labour and farm machinery is greater on large farms. Finally, there is some evidence that the use of capital inputs on large farms and their relatively favourable access to credit have been encouraged by public policy.

It is by now well known that in Pakistan the subsidization of agricultural inputs and credit has been an integral part of what some have called a "bimodal" strategy of agricultural development. It is also well known that the subsidization of inputs to encourage their use almost always introduces imperfections in factor markets, as indeed is true of most capital inputs in many underdeveloped countries. Further, a subsidy can be an instrument of encouraging socially desirable transfers of income. However, as Pakistan's experience shows, this may not have been the best way to achieve the intended goal of parity among sectors or income groups. In view of the heavy reliance on subsidy on agricultural inputs in Pakistan and the fact that the access to these inputs has been unequal between large and small farms, one wonders if the income transfers have not been from the weak to the strong!

The results of this study suggest that the greater use of non-traditional inputs on large farm in Pakistan can be traced to market imperfections buttressed by public policy. Therefore, the central thrust of the public policy should shift to an elimination of such policy-induced distortions. More competitive markets for land, labour and capital can best be achieved by land reforms, which, among other things, introduce such measures as a ceiling on land-holdings, greater dispersion of extension services and greater availability of farm credit. Land reforms should be a means to reducing oligopolistic and oligopsonistic elements in the economy [7].

Received September, 1978; final version received February, 1979

\section{REFERENCES}

1. Bardhan, P. K. "Size, Productivity and Returns to Scale: An Analysis of Farm-Level Data in Indian Agriculture." Journal of Political Economy. November/December 1975.

2. Berry; R. A. and W. R. Cline. "Farm Size, Factor Productivity and Technical Change in Developing Countries." June 1976.(Mimeographed).

3. Dalrymple, D. "Evaluating Fertilizer Subsidies in Developing Countries." A.I.D. Discussion Paper No. 30. Washington, D.C.: July 1975.

4. Griffin, K. The Political Economy of Agrarian Change: An Essay on the Green Revolution. Cambridge, Mass. : Harvard University Press. 1974.

5. Heady, E. O. and J. L. Dillon. Agricultural Production Functions. Ames: Iowa State University Press. 1961.

6. Khan, M. H. The Economics of the Green Revolution in Pakistan. New York: Praeger Publishers. 1975.

7. Koo, A.Y.C. "An Economic Justification for Land Reformism." Economic Development and Cultural Change. April 1977.

8. Pakistan. Agricultural Census Organization. Pakistan Census of Agriculture 1960. Vol. II. West Pakistan. Karachi. 1963.

9. - _ Agricultural Census Organization. Pakistan Census of Agriculture 1972. Vol. I. All Pakistan Report. Lahore. 1976.

10. - - Ministry of Food, Agriculture, Cooperatives, Underdeveloped Areas and Land Reforms. Agricultural Statistics of Pakistan 1975. Islamabad. 1975. 